\title{
CRISE NO DIREITO BANCÁRIO: FENÔMENO CONTRATUAL, RELAÇÃO BANCO/CLIENTE, PODER INSTITUCIONAL E PROTEÇÃO DO CONSUMIDOR.
}

\author{
Fabricio Pasquot Polido \\ Aluno do Curso de Graduação da Faculdade de Direito da \\ Universidade de São Paulo. \\ "Entre o forte e o fraco, \\ a liberdade escraviza e a lei liberta." \\ Lacordaire
}

Resumo:

O objetivo básico deste trabalho é inserir alguns problemas do Direito Bancário num contexto de aperfeiçoamento e transição, como fatores de crise. A abordagem principal propugna pelo exame de alguns aspectos centrais do Direito contratual brasileiro e suas transformações, da relação Banco/cliente, os papéis assumidos e o fenômeno contratual envolvido nas práticas e operações bancárias. Do mesmo modo, o poder institucional do Banco é revelado em sua capacidade de criar normas e desenvolver contratos complexos. Finalmente, verifica-se a questão da proteção do consumidor dentro do Direito Bancário e propõe-se uma nova alocação dos contratos através da utilização de princípios existentes na sistemática brasileira da defesa do consumidor. Assim, será possivel obter a construção de uma análise panorâmica sobre alguns enfoques elementares revelados pelo Direito Bancário no início do século XXI.

\begin{abstract}
:
The basic purpose of this paper is to insert some banking law matters in an improvement and transition context as crisis features. The main approach claims to an exam about central aspects of Brazilian contractual law and its changes, about Bank/client relationship and the contractual phenomenun envolving banking practices and operations. In the same way, the institutional power of the Bank is exposed in its skill of creating norms and enforcing complex contracts. Finally, it refers to the problem of consumer's protection inside banking law and it recommends to a new model of contractual principles of Brazilian consumer's law system. Such case, it will be possible to build a global analysis that involves some elementary points revealed by banking law in this 21 's century beginning.
\end{abstract}

* Integrante do "Grupo de Monitoria c Pesquisa do Departamento de Dircito Comercial da FDUSP" Monitor da Disciplina Tcoria Geral do Dircito Comercial. Ex-bolsista do Programa Institucional de Bolsas de Iniciação Cientifica-PIBIC, do CNPq, junto ao Departamento de Dircito do Estado da Faculdade de Dircito da Universidade de São Paulo. 
Unitermos: banco, cliente, contratos bancários, poder institucional, defesa do consumidor, princípios contratuais.

\section{I - Considerações Preliminares}

A frase em epígrafe, reiteradamente invocada pelos juristas antigos, ilustrou, no passado, uma discussão que pôs em evidencia os problemas mais comuns que a contratualística clássica apresentava. $O$ ocasional desequilíbrio entre as partes envolvidas em determinados contratos e a crença na força da lei como único instrumento hábil para corrigir tal deformidade justificavam formalmente tal assertiva. Em decorrência dessa concepção, restou evidente uma pressão para que o próprio sistema de Direito Privado fosse reformulado em suas bases: princípios como a autonomia da vontade, pacta sunt servanda e relatividade dos efeitos contratuais foram, pouco a pouco, levados a um processo de mitigação, principalmente em face do sintoma de repulsa ao individualismo criado pelo liberalismo econômico.

A expressividade de um tempo dominádo pela racionalização das instituições: a Família, a Escola, a Igreja, a Empresa, todos setores coadjuvantes e dependentes de mútuo relacionamento, fez com que a sociedade repensasse as práticas contratuais que contribuíssem ainda mais para um regime de desigualdades econômicas, um regime massificado, em que igualdade de todos perante a lei mostrava-se um axioma impraticável, quando não muito uma falácia do Direito Positivo para alimentar esperanças em torno de um sistema supostamente voltado para o privilégio da Justiça. Dentro desse quadro, não foi mais possível pensar no Direito contratual como a única e mais formidável invenção do capitalismo, porém admitir a hipótese de que novos enunciados precisavam ser criados para a reflexão da sistematicidade do próprio fenômeno jurídico, identificando uma regra como aplicável ou não a determinado problema.'

A partir daí, tanto a nova ordem de produção do mercado, baseada na especialização da economia, bem como o modelo welfarista (em que um Estado intervencionista age diretamente na esfera privada, por meio de politicas legislativas diretas), ambos em auge no Pós-Guerra ${ }^{2}$, determinaram novos contornos para o Direito

1. Porto Macedo Jr., Ronaldo, Contratos Relacionais e Defesa do Consumidor, São Paulo, Max Limonadc, 1998. pp.44-45. Vale ressaltar tambćm que isso fora uma reação contra a omissão do Dircito Positivo diante dos abusos concernentes à livre contratação entre as partes, em que dois focos de poder são detcctáveis, mas cntre cles cxiste nítido desequilibrio. Por conta disso, novos mecanismos foram scndo rcsgatados do passado, como, por cxcmplo, a cláusula rebus sic stantibus, do Dircito Canônico, a permitir a intervenção no conteúdo dos contratos através de sentença judicial que produza os cfeitos não concluidos, quando $\mathrm{cm}$ situações de desequilibrio das partes c superveniência de fatos cconômicos

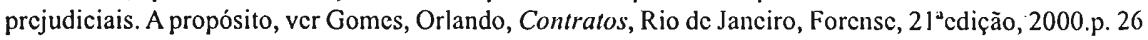

2. Tratava-se justamente do momento propício para a adoção de medidas de plancjamento a priorizar a humanização das arbitraricdades do mercado de trocas, a realização de determinadas finalidades públicas c concretização de um modclo cstatal de todas as classcs. A propósito, Rocha Scott, Paulo Henrique, Direito Constitucional Econômico: Estado e Normalização da Economia, Porto Alcgre, Scrgio Fabris Editor, 2000. especialmente pp.54-62 
contratual como, por exemplo, a crença nas medidas protetivas do interesse social e o complexo normativo do respeito à ordem pública. Criou-se o paradigma do controle social, no qual a concepção tradicional de mercado não seria causa dos contratos, vez que qualquer que fosse a forma econômica organizada pela sociedade, não poderia ela atender a escolhas meramente voluntárias, mas estar condicionada às produções em massa. Daí, por exemplo, o advento de inúmeras leis em favor da proteção do consumidor. $^{3}$

Esse modelo de intervenção e controle estatal, entretanto, vem gradativamente se enfraquecendo, principalmente em face do cenário contemporâneo sustentado pela globalização econômica, revolução tecnológica e institucionalização dos conglomerados empresariais. Conquanto as relações de troca, as regras de satisfação de necessidades e os conflitos de interesses têm sido renovados em suas perspectivas, o que dá ao Direito contratual efetiva reorientação, enfrenta-se hoje um periodo de transição dos modelos. Dentro desse fenômeno (se assim se puder chamar), o Direito em sua unidade é colocado em questionamento, os seus paradigmas são reformulados, de modo a se conceber, para tal contexto, a denominação "crise da Pós-modernidade" 4 O que se vê são dúvidas pós modernas: a revolta de uma Ciência, realidade que o jurista geralmente não gosta, mas que, pelo menos, suscita, no novo milênio, indiscutível proposta de reflexão. ${ }^{5}$

Considerando que o Direito contratual é uma das principais peças dessa engrenagem atípica, os seus segmentos ficam comprometidos em sentido e extensão. Sentido porque, a cada dia, existe uma tendência para a especificação do fenômeno unitário que a contratualística outrora comportava. Hoje existem ramos com regras próprias - o fenômeno da "pulverização sistêmica". que leva à perda da concepção de contrato, enquanto conjunto de promessas voluntárias e passa a contratos como conjunto de elementos especializados, como os administrativos, os internacionais, os de consumo e os bancários. Extensão, porque o contrato não mais atende a uma simples declaração bilateral de vontade, mas uma fonte de interesses voltada para regulação de transações

3. No Brasil o marco ć a lei 8078/90, o Código de Defesa do Consumidor, cuja implicação para a Tcoria dos Contratos ć bastante conclusiva. Até então, apenas o Código Comercial de 1850 c o Código Civil de 1916, produtos de uma socicdade agricola c incipientemente industrial cram os mecanismos de regulação das práticas contratuais. A defesa do consumidor já cra realidade na Europa, como $\mathrm{cm}$ Portugal (DL n.446/85) c na Alcmanha (ABG-Gesctz ). cf. Coclho, Fábio Ulhôa. O Empresário e os Direitos do Consumidor, São Paulo, Saraiva, 1994. pp. 123 c ss.

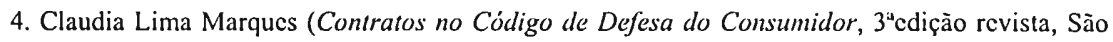
Paulo, RT, 1998. pp. 90 c ss.) preferc não utilizar a cxpressão "Crisc da Pós Modernidade", porćm reconhece que a socicdade contemporânca tem passado, de um modo geral, por um periodo de incertezas, de ruptura Umbruch, (scgundo terminologia alcmã), inicio de uma situação ainda não muito bem identificada. Talvez scja a descontiança acerca da suficiência do próprio Dircito para a filtragem dos problemas que a sociedade identifica no dia a dia.

5. Junqueira Azcvedo, Antonio. "O Dircito Pós Moderno c a Codificaçào". In Revista da Faculdacle de Direilo da Universidade de São Paulo, vol.94, Serviço Técnico de Imprensa, 1999. pp.3-11 
econômicas complexas e a desempenhar um papel de alocação de poder e riqueza. ${ }^{6}$ Do mesmo modo, em muitas situações, os valores nucleares que movem a contratualística revelam que as partes contratam, porque entre elas já existe um vínculo de dependência, sustentado pelas necessidades do mundo atual, além das pressões de consumeirismo e estabilização financeira.

Pois bem, feita essa exposição preliminar, em que se apresentou uma breve perspectiva do Direito contratual em sua transitoriedade, é provável que o sistema de Direito Bancário, tradicionalmente tido como complexo de operações técnicojurídicas entre indivíduos: de um lado, o cliente e, de outro, a Empresa autorizada a exercer uma atividade financeira o Banco ${ }^{7}$ tem sido beneficiado por todas as transformações acima mencionadas. A essência da relação Banco/cliente se altera, já que o vínculo que a encerra envolve situações determinadas por variáveis específicas, como as que serão abordadas mais a frente, de modo a revelar que a maior ou menor ligaçã்o entre os sujeitos envolvidos não se define por simples acordo de vontades $\mathrm{e}$ que a realidade em exame merece atenção, principalmente quando se pretender um modelo protetivo eficaz, porquanto o cliente dele precise, e de crescimento, porquanto o Banco também deste não vai se dissociar.

Através deste trabalho, a questão das relações contratuais dentro do âmbito bancário será explorada, ainda que brevemente, em torno dos sujeitos envolvidos, papéis que cumprem, de um lado a Empresa - instituição financeira, fornecedora, intermediadora e, de outro o cidadão, o consumidor, o usuário, o fenômeno contratual manifestado no Direito Bancário e seus problemas, o poder institucional do Banco e sua conexão com a difusão dos contratos, além da questão da caracterização da defesa do consumidor pelo tocante às relações bancárias e propostas para um modelo protetivo. Desse modo, longe de expor detalhadamente a dogmática dos esquemas encetados, porque isso já tem sido feito reiteradamente pela doutrina ${ }^{8}$ propõe-se levar a cabo uma análise panorâmica de algumas peças do Direito Bancário, num momento em que ele se modifica profundamente, convivendo também com uma série de impasses que afetam o sistema: contradições entre normas produzidas, divergências nos tribunais, abusividade, inadimplência e altos indices de litigiosidade.?

6. Diante dessa perspectiva, a Empresa, o sindicato, as associações tornam-se centros produtores de normas, ditando interesses, consolidando o pólo de poder na rclação contratual. Assim, todas as transaçõcs entre comerciantes c consumidores, por excmplo, criam mecanismos de satisfação de necessidades, gerando um diferencial de poder $\mathrm{cm}$ função da própria posição do contratante no mercado, bcm como de sua posição relativamentc a composição de interesses, como no caso da relação banco/clicnte c a de Empresa/ funcionário. cf Porto Macedo Jr, Ronaldo, ob.cit., cspecialmcntc pp.5l c ss.

7. cf. Covcllo, Scrgio. Contratos Bancários, 2 "cdição, São Paulo, Saraiva, 1991.p.40

8. Cf.Rizzardo, Arnaldo. Contratos de Credito Bancário, 4: cdição, Sào Paulo, RT, 1999. especialmente pp.10 e ss; Gomes, Orlando, op.cit, pp.326 e ss c Mcllo Casado, Marcio, Proteção do Consumidor de Crédito Bancário e Financeiro, São Paulo, RT, 2000. pp. 15 c ss.; Covcllo, Scrgio ob.cit., cspecialmente 43 c ss.

9. A propósito, Wald, Arnoldo. "A Patologia do Dircito Bancário: causas e soluçõcs", in Revista de 


\section{II- Relações Banco/Cliente}

1. Distinção entre papéis.

As relações bancárias, encaradas sob a égide de um complexo de operações numéricas e qualificadas num contexto técnico-jurídico que despersonaliza os sujeitos, determinam a distinção de papéis relevantes, quer no enfoque daquele que promove as relações, isto é, o Banco, quer no enfoque daquele que se utiliza das relações, o cliente. Essa abordagem é interessante para descrever o modo que a relação Banco/ cliente é coordenada, sendo que tal hipótese ainda será analisada para melhor explicitar o problema em exame no presente trabalho. ${ }^{10}$

Como analisou Jean Escarra" o Banco atrai o público, exercendo nele um poder de ordem material, psicológica e moral. O maior de todos, entretanto, é sem dúvida o poder de conferir crédito, porquanto se leve em conta a confiança daqueles que recorrem à instituição. O Banco não é apenas um ente autorizado a funcionar como tal, revestido da forma que o Direito impõe, isto é, a instituição financeira revestida de personalidade juridica de cunho público ou privado e que tenha como atividade principal a coleta, intermediação ou aplicação de recursos financeiros ou de terceiros em moeda tradicional ou estrangeira e a custódia de valor de propriedade de terceiros (e.g. regra do art. 17 da Lei n. 4.595/64). Ele é uma instituição dotada de poder financeiro, contratual, intermediador e de vinculação. Na medida em que todos esses focos interagem, as relações bancárias tornam-se necessárias e impõem, às partes envolvidas, compromissos múltiplos e recíprocos. Nessa perspectiva, o elemento confiança investe-se de singularidade, já que o cliente se vale desse atributo em relação ao Banco e vice-versa ${ }^{12}$. Desde logo o suporte à relação é um nexo não apenas jurídico, porque, se assim fosse, ter-se-ia uma justificação na contratualística tradicional, porém de uma vinculação intersubjetiva, em que as partes se completam mutuamente.

Direito Bancário e Mercado de Capitais, n.7, Ano 3, janciro-março, São Paulo, RT, 2000, pp.36-52 c Wambicr, Luiz Rodrigucs. "Contratos bancários c o Código de Defesa do Consumidor", in Revista dos Tribunais, n.742, ano 86, São Paulo, RT, 1997. pp.57-68

10. cf. sç̧ào III infra.

II. Principes de Droit Commercial. Paris, Librairic du Recucil Sircy, 1936. pp.116. A propósito de considerar que o Banco concentre $\mathrm{cm}$ si atrativos variados, que luvvam o cliente à satisfação de suas necessidades c à garantia de proteção, o autor assinala: "La qualité Zlu personnel la façon dont il sait se faire apprécier du client, la bonne exécution dh travail, out aussi une tres grande importance. La diffission des sieges, leur bom enplacement, le luxe et le confort des installations ne sont pas à négliger; mais il ne faut pas s' éxagérer leur influence: les gouits de la clientéle, à cet egard, sont assez divess ".

12. A respeito do clemento confiança, Sćrgio Covello, ob.cit. p.38, analisa: "Importa a confiança que o individuo inspira no tocante à honestidade, à solvabilidade, à vontade de cumprir as obrigaçòes contraidas; dai o rigoroso serviço de cadastramento e informaçōes que os Bancos mantêm entre seuss serviços para aquilatar essa virtudes no cliente antes de celebrar: Importa a confiança que o banco inspira na coletividade, por meio da honestidade, da solvabilidade, da segurança, sigilo nas operaçôes e na precisão dos serviços que presta." 
Havendo uma interdependência necessária, os elementos que compõem uma determinada relação dentro da atividade bancária distinguem-se por seus papéis. O Banco é sujeito-empresa, sujeito-fornecedor e sujeito-intermediador, vindo a exercer funções variadas: i. administração da moeda, com significado de sistematizar um crédito elástico que proporcione necessário desenvolvimento econômico; ii. mecanismo de pagamentos e transferências de fundos, em que os títulos de crédito, como os cheques, são sacados e depositados; iii. agregar poupança, no sentido de reunir recursos e disponibilizá-los para fins econômicos desejáveis, além de remunerar o poupador através de pagamento de juros e garantir-lhe a devida proteção de seu dinheiro; iv. estender o crédito, isto é, disponibilizar, sob a forma de empréstimos, o que poderá viabilizar de alguma forma a atividade do cliente, seja ela agrícola, comercial, ou industrial, além de destino a consumo próprio; v. prover serviços de corretagem, com a compra e venda de ações e vi. vender produtos, como cartão de crédito, cartão 24 horas, planos de saúde, seguros de vida, de residências e de automóveis. ${ }^{13}$ Para exercer essas tarefas, os Bancos conformam-se enquanto instituições comerciais, a realizar "operações a varejo" tais como depósitos, descontos, abertura de crédito, empréstimos pessoais para consumo, prestações de serviços e de cobranças de toda a espécie, instituições de crédito industrial, como ao conceder empréstimos de longo prazo para as indústrias a fim de que elas obtenham recursos para modernização de seu maquinário e também instituições de investimentos que realizam "operações ao atacado" sob a forma de participação e financiamento a médio e longo prazo com intento de gerar suprimento de capital, quer oriundos de recursos próprios, quer de recursos tomado de terceiros (clientes ou outros Bancos).$^{14}$ Hoje, verificando-se que atua em muitos setores ao mesmo tempo, o Banco também não fica fora da incidência dos efeitos da globalização econômica, vindo a se remodelar em função de vários fatores, como a comunicação eletrônica, a volatilidade da moeda, a disseminação das transações internacionais ${ }^{15}$, a ampliação de um ambiente competitivo e a transição do modelo de regulação a que está submetido. ${ }^{16}$

No outro pólo da relação, existe o cliente, que é sujeito-cidadão, sujeitoconsumidor e sujeito-usuário. Cidadão, enquanto destinatário de normas constitucionais, concentrando em si direitos e deveres. O conjunto de cidadãos forma um grupo social que tem expectativa à consolidação de prerrogativas, como quando na hipótese de estar tutelado pela ordem econômica, tendo em vista a livre iniciativa e a valorização do trabalho. ${ }^{17}$ É também consumidor, porquanto se encontre numa cadeia de consumo,

13. Recd, Edward W c Gill, Edward K. Bancos Comerciais e Múltiplos, São Paulo, Makron Books, 1994. pp.3-7

14. cf. Covello, Sergio Carlos, ob.cit., especialmente pp.19-21

15. cf. Wald, Arnoldo, "A Patologia do Dircito Bancário: causas c soluçõcs”, p.43

16. cf. Salomão Filho, Calixto. "Condutas Anticoncorrenciais no Sctor Bancário" In Revista de Direito Mercantil, n.114, ano XXXVII, abril-junho, São Paulo, Malhciros, 1999. Especialmente pp. $69 \mathrm{c}$ ss; Recd, Edward W c Gill, Edward K., op.cit., pp. 13 c ss.

17. Casado, Márcio Mcllo. Proteção ao Consumidor de Crédito Buncário e Financeiro, São Paulo, RT, 2000. pp.2I c ss. 
enquanto utilize um bem ou serviço para si, ou para que seu padrão de vida possa ser melhorado. Por outro lado, ainda que não seja o destinatário final da cadeia de consumo, pode haver situações em que o cliente-consumidor esteja, por necessidade, desempenhando esse papel, tendo que empregar o bem ou serviço obtido para o incremento de uma atividade que desempenha. ${ }^{18}$ Também é usuário, enquanto indivíduo que, condicionado pela força da mídia - rádio, televisão, revista e Internet, é induzido a contratar, vindo a adquirir novos recursos para satisfazer suas necessidades. ${ }^{19}$

A dimensão de como os elementos da relação Banco/cliente se arranjam envolve um conhecimento de seus papéis e de suas distinções e que, diante de sua particularidade, dá informações básicas para as perspectivas de um regime contratual em mudança.

\section{Regime contratual em crise}

\subsection{Análise do fenômeno contratual bancário e suas manifestações}

Sempre houve dificuldade de se admitir o Direito Bancário enquanto um ramo autônomo do Direito, principalmente por sua submissão histórico-normativa ao Direito Comercial. O que se observa geralmente, dentro da questão da pluralidade sistêmica, é a existência de uma facção do Direito Privado a prever a organização do Sistema Financeiro, regulando as atividades das instituições de crédito e sociedades financeiras. Todavia, o Direito Bancário, ao assumir correspondência à disciplina jurídica dessas entidades, acaba subjugando-se também às regras de Direito Público. Isso ocorre no tocante do Direito Administrativo, enquanto se atribui ao Banco Central, por exemplo, a tarefa de fiscalizar e supervisionar a atividade desenvolvida pelas instituições financeiras, e também pela a influência do Direito Econômico, primordialmente quando informa a tutela da livre-iniciativa, proteção da concorrência e da poupança popular. Nesse contexto, enfim, estão inseridas várias circunstâncias que, teoricamente, propugnam pela orientação sistemática do Direito Bancário, de um lado em seu arcabouço de operações jurídicas e, de outro, dos interesses coletivos e difusos a serem assegurados. ${ }^{20}$

Todavia o grande problema não é o questionamento sobre a autonomia. $\mathrm{O}$ tratamento do Direito Bancário dentro de regimes contratuais, que não sejam rígidos e carentes de funcionalidade, é que tem sido a grande dificuldade na boa compreensão

18. Efing, Antônio Carlos. Contratos e Procedimentos Bancários à Luz do Código de Defesa do Consumidor, Sào Paulo, RT, 1999. pp.39

19. cf. Lima Marques, Cláudia Lima, ob.cit., pp. 53 c ss; Casado, André Mcllo, ob.cit., p.17

20. A propósito, ver Menczes Cordciro, Antonio. "O Dircito Bancário Privado". In Direito Bancário: Actas do Congresso Comemorativo dos 150 anos do Banco Central de Portugal. Suplemento da Revista da Faculdade de Dircito da Universidade de Lisboa, Coimbra, Coimbra Editora, 1997. pp. 18 c ss.; Abrão, Nclson, Direito Bancário, $3^{\lrcorner}$cdição, São Paulo, RT, 1996. 
do tema, já que existe uma série de variáveis que implicam a dinamização dos elementos envolvidos na relação Banco/cliente. Como abordar o fenômeno contratual no âmbito bancário, quando ao jurista são apresentadas situações dotadas de complexidade, em que a simples aplicação de normas jurídicas nem sempre dá resposta satisfatória aos conflitos que ocorrem no contexto das relações travadas?

Há um bom tempo, descobriu-se que os esquemas calcados no Direito Civil e no Direito Comercial tornaram-se inadequados para o tratamento da economia de massa, não atendendo às reais situações das partes envolvidas, principalmente quando exigências sócio-econômicas, baseadas nos serviços, na informatização e flexibilização do mercado foram se intensificando. ${ }^{2 !}$ Banco e cliente figuram nesse contexto, enquanto, de um lado, tem-se a Empresa fortalecida em seu poderio financeiro-institucional e, do outro, um indivíduo qualquer, quer ele o cidadão, quer o pequeno e médio empresário, ambos não muito bem informados e muitas vezes carentes de garantias que possam conferir, às relações contratuais estabelecidas, o tão discutivel binômio "segurançaestabilidade"

Atualmente, existe um distanciamento do conceito antigo que se tinha de atividade bancária, isto é, de estar ela enquadrada na categoria de ato de comércio e regida por uma série de formas por força da natureza que assume..$^{22} \mathrm{~A}$ tendência generalizada confirma a preferência de os Bancos contratarem por meio de cláusulas contratuais gerais e contratos de adesão, como outrora reconhecia Orlando Gomes ${ }^{23}$ principalmente porque as instituições financeiras têm necessidade de se organizarem para que suas relações jurídicas possam se travar de modo uniforme e simples com uma série indeterminada de clientes. Daí a padronização dos esquemas e cláusulas contratuais mediante fórmulas homogêneas, geralmente impressas e simplificadas. Do mesmo modo, não há lugar para a negociação individual numa lógica que leva em conta padrões gerais de comercialização, projeção de valores, simulações de cálculos complexos e análises macroeconômicas. A contratação por adesão tem sido, nesse iter, uma exigência de ordem prática dentro do sistema bancário, voltada para uma estimativa empresarial, pela qual a instituição financeira visa buscar a satisfação das necessidades operacionais, - como a venda de produtos, cartões e títulos de capitalização e a provisão de crédito elástico, o qual é captado do público e, mediata ou imediatamente, destinado

\section{1. cf. Coclho, Fabio Ulhôa, ob.cit., pp. 128}

22. Assim como no artigo 120 do Código Comercial de 1850 , cm que "as operações de Banco serào decididas e julgadas pelas regras gerais dos contratos estabelecidos neste Códligo, que forem aplicáveis segundo a natureza de cadla uma das transações que se operarem". Do mesmo modo, o regramento dado pelo Regulamento n. 737//850, a considerar a atividade bancária como ato de comércio, como se via tradicionalmente no passado. Em analogia, o Dircito francês também reputa comerciais as operações bancárias (como no art. 632 do Code de Commerce de 1807), nas quais, como cxplica Jean Escarra, ob.cit., p. 126 c ss., configura-se o vínculo entre o pólo comerciantc- o Banco- c o nào-comerciantc- 0 clicnte. Eis portanto, a visão que se tcm, na maioria das vezes, quando o contrato bancário é abordado cm scus pressupostos dogmáticos.

23. ob.cit., especialmente pp. 324 c ss. 
a atividades e negócios variados. Do outro lado, resta ao cliente aceitar, enquanto precise, tem interesse, ou requer fomentar alguma atividade que exerce, seja ela de cunho pessoal ou coletiva. ${ }^{24}$

Existe uma razão que vem acentuar a prática da adesão disseminada no contexto da relação Banco/cliente. A homogeneização das necessidades, na verdade, fruto da indução ao consumeirismo, da associação à publicidade e métodos agressivos de marketing, além da promessa de garantia de conforto após a morte e contra a incerteza das relações a serem constituídas no futuro, vem difundir a tratativa por adesão no Direito bancário. Com isso, a duração dos vínculos contratuais, (porquanto não exista apenas um, mas uma conexão deles), tende à longevidade, estendendo-se no tempo. ${ }^{25}$ Os contratos bancários, em geral, inserem-se nesse esquema, já que passam a envolver feixes de obrigações que prometem qualidade e segurança, e, desse modo, adquirirem a nota de continuidade no tempo. Isso é evidente, já que a ligação fundada na necessidade se completa, seja porque o Banco (instituição, fornecedor e intermediador) procure a maximização de lucros e serviços, seja porque o cliente (cidadão, consumidor e usuário) esteja orientado pela segurança, pressão de consumo e garantia contra riscos. Nesse sentido, é bem provável que uma cadeia normativa é consignada entre o Banco e o cliente, e o sistema de contratação gerado vem informar um conjunto de obrigações dotadas de prestações continuadas, cuja nota essencial é prolongarem-se no tempo.

As hipóteses de relações contratuais em que isso ocorre são variadas e cada qual tem uma particularidade. A abertura de conta corrente ilustra a problemática de modo bem claro. Nela, Banco e cliente travam uma relação de "dever" e "haver", na qual coexistem depósitos e pagamentos vinculados. Para que essa operação se maximize, quantitativamente, nas instituições bancárias, a contratação se dá pela adesão do cliente às fórmulas pré-elaboradas - pouco lidas e conhecidas -, mas que, em sua amplitude, permitem a conexão jurídica com outras espécies de operações bancárias, tais como o crédito ao consumo, pagamentos em débito automático, transferências, carteiras de títulos, constituições de garantia, além prestações acessórias como o seguro e assistência médica ${ }^{26}$ Nesse caso é visível a vinculação do cliente ao Banco, já que através de uma simples operação, qual seja, a conta corrente, é possivel que uma relação complexa seja engendrada, encadeando outras operações propicias ao desenvolvimento da atividade bancária. Através de um único contrato, vários negócios são mediatamente celebrados e se prolongam no tempo, de modo que o cliente-cidadão-usuário esteja envolvido por inúmeras prestações de ordem técnica e relacional. Um exemplo

24. Coclho, Fábio Ulhôa, ob.cit., pp. 129 c ss; De fato, o cliente, com grande freqüĉncia, sequer lê as cláusulas impressas, principalmente pela falta de tempo, falta de informação, pela confiança que tem no banco ou porque precisa, emergencialmente, do dinhciro à mão. Ainda que discorde, pouco resultado prático conscguirá - ou accita, ou rejcita na totalidade, já que a parcialidade não surtc cfeitos no campo dos contratos de adesão. Por isso, o cliente vem se submeter a uma composiçào de regras $\mathrm{c}$ não ao velho csquema da $<$ declaração de vontades $\gg>$. cf. Rizzardo, Arnaldo, op.cit., p. 23

25. cf. Lima Marques, Cláudia, ob.cit., pp.68 c ss.

26. cf. Menczes Cordciro, Antônio, ob.cit., pp.28 c ss 
interessante é a abertura de crédito, geralmente conexa à conta corrente. Tal operação, tida tradicionalmente como ativa (porque o Banco disponibiliza o crédito e o direciona para o cliente) ${ }^{27}$, atinge índices de freqüência altíssimos dentro da atividade bancária, em que o tomador pode se valer de uma "programação de uso" dentro de suas necessidades, ocasiões e prazos estipulados, como maneira de evitar a perda monetária. Estando vinculada à conta corrente, o Banco tem um controle elementar da operação, -já que remete ao cliente determinada quantia a ser utilizada-. mas não pode simplesmente cortar o crédito no curso do contrato quando este tem prazo determinado, o que seria o exercício de uma condição meramente potestativa. ${ }^{28} \mathrm{~A}$ situação em tela, todavia, não é tão simples quando o referencial contratual é a operação de conta corrente, geralmente sem um prazo determinado, dotada de prestações continuadas e geradoras de outras operações. A adesão feita pelo cliente implica multiplicação de prestações, ficando ele adstrito ao Banco, sem muita oportunidade de interferir nas relações jurídicas desencadeadas.

Do mesmo modo, o crédito pessoal ou individual, produto que geralmente atinge tanto o cidadão comum, quanto a classe dos profissionais liberais, é mecanismo bastante simplificado para a concessão de crédito, adquirindo a dimensão de um empréstimo para consumo. O vínculo relacional estabelecido entre as partes envolvidas é influenciado pelo consumeirismo ${ }^{29}$ que, enquanto variável de teor econômico, determina a aproximação entre as partes e, assim, a vigência do contrato firmado se estende no tempo. Quanto maior a quantia que o Banco empresta ao cliente, maior o intervalo de tempo para a execução das prestações contratuais. Além disso, há a circunstância de que o crédito pessoal pode ser destinado ao universo empresarial, ganhando a feição dúplice de crédito comercial e crédito industrial, tendo o escopo de fomentar as atividades desenvolvidas pela Empresa, seja na aquisição de serviços, no investimento em maquinário ou na melhoria de sua atuação no mercado. Assim, um número significativo de clientes é recepcionado pelo Banco, mesmo porque, o crédito individual, além de instrumento de intermediação, é também um produto a ser comercializado pela instituição bancária, em que pesem os esforços de divulgação e

27. cf. Covello, Sergio Carlos, ob.cit., p.28. O funcionamento desse mecanismo contratual sc dá basicamentc: I. o cliente tem para si a disponibilidade de crédito até o montante acordado. Pode cle cfetuar retiradas, scja $\mathrm{cm}$ dinhciro, scja $\mathrm{cm}$ forma de cheque, de uma só vez, ou parceladamentc. Ter a disponibilidade de crédito não importa que o cliente tenha a titularidade do mesmo; 2 . Uma vez tendo aproveitado o crédito, o clicnte já ć proprictário e devedor e dai o fato de o banco poder cobrar juros c encargos de manutenção do serviço. 3. Tecnicamente, c havendo inadimplemento, a divida pode ser cobrada segundo o artigo 585 do CPC, incluidos os juros, correçào monctária c cncargos. cf. Rizzardo, Arnaldo, ob.cit., pp. 53 c ss

28. cf. Gomcs, Orlando, ob.cit.p. 329

29. A respeito do binômio consumo/necessidade, Scrgio Coycllo, ob.cit., p.42, analisa: "O crédlito pessoal não raro representa um crédito de consumo. Quem solicita esse tipo de crédito ao Banco o faz porque precisa comprar objetos de sua necessidade. É o crédito tipico para aquisição de bens e serviços. que hoje em dia, são de uma constância extraordinária. 
investidas de marketing. A relação estabelecida em ambos os casos, quer para cidadão, quer para o empresário, orienta-se por variáveis ligadas à necessidade e à pressão de consumo, de modo que o cliente, muitas vezes, move-se pela falsa impressão de um negócio bem acabado e vantajoso, além de receber informação deficiente no que concerne às técnicas e condições do crédito objetivado, bem como desconhecimento acerca dos direitos e obrigações resultantes da utilização dessa operação. ${ }^{30}$ Consequentemente, para simplificar todo procedimento dessa operação, do ponto de vista jurídico, nada mais efetivo do que a utilização do contrato de adesão, que acelera a contração entre Banco e cliente, permitindo a homogeneização das relações criadas.

Outra situação também ilustrativa está na construção da figura do cartão de crédito, bastante singular na atividade bancária contemporânea. Desde sua invenção, nos Estados Unidos, já no início da década de 20, e curiosamente com o intuito de as grandes Empresas atraírem uma clientela de confiança para depois mantê-la como consumidora de seus produtos, o cartão de crédito permite identificar o seu portador, habilitá-lo ao crédito e atribuir-lhe o dever de pagamento posterior. Para isso, existe um feixe de contratos implícitos que revela a existência de uma relação trilateral entre o titular do cartão (cliente), o emissor (Banco) e o fornecedor (qualquer um que aceite o valor pecuniário contido no cartão em contraprestação de um bem ou serviço fornecido). Geralmente, o Banco se utiliza do expediente de um contrato de adesão que contém cláusulas de outorga de poderes para o titular escolher o fornecedor que aceitar o serviço, e assim, negociar com o fornecedor o crédito embutido no cartão. Por outro lado, o emissor é dotado de poderes mais amplos, como o de esfacelamento da prestação contida na relação gerada pelo contrato de adesão em prestações conexas, quais sejam, o financiamento a curto prazo com juros compensatórios, o débito automático em conta corrente do cliente ou a emissão de título representativo para o débito encetado. ${ }^{31}$ Do mesmo modo, perfazendo a categoria de um produto comercializado pela instituição emissora, o cartão de crédito tem sido utilizado com grande freqüência na atividade dos Bancos. Isso explica a vantagem de cláusulas contratuais gerais serem estabelecidas, as quais podem, otimizando as negociações, permitir que um tempo maior seja dispensado para a publicidade e aprimoramento do serviço ligado ao cartão, daí sua proliferação no mercado enquanto instrumento propulsor do consumeirismo e amostra de crédito simplificado.

\subsection{Implicações práticas desencadeadas pelos contratos bancários}

Os exemplos acima revelam, a grosso modo, como as operações bancárias se comportam diante de um regime contratual que envolve as partes Banco e cliente

30. Stiglitz, Gabricl A. Proteção Juridica del Consumidor, $2^{4}$ edicción actualizada, Bucnos Aires, Depalma Editora, 1990. pp.55 c ss.; 
em uma série indefinida de situações que explicitam necessidade, vinculação intersubjetiva e consumeirismo. Justificado o mecanismo de que a instituição bancária pode se valer, a tarefa de isolar os fenômenos criados exige uma análise de como se comportam os resultados práticos dos negócios estabelecidos, isto é, quais as conseqüências comuns às relações jurídicas firmadas.

O mesmo problema no Direito português, por exemplo, ilustra bem o que acontece com a expẹriência contratual no âmbito bancário. Tem sido muito freqüente que o Banco elabore suas próprias cláusulas contratuais gerais, padronizando-as dentro de um setor exclusivo da economia por ele dominado. Tal situação vem trazendo, nas últimas décadas, como analisa Oliveira Ascensão ${ }^{32}$ um certo "desconforto jurídico" no que concerne resolver especificadamente cada questão em que a relação Banco/cliente se manifesta, vez que, se não remeter o jurista ao puro casuísmo, impede que uma disciplina geral sobre o problema, dentro do sistema de Direito Bancário, seja criada. Isso requer, na maioria das vezes, a aplicação de regras gerais aos contratos de adesão estabelecidos pelos Bancos, abundantes de "cláusulas de surpresa", tais como as que são redigidas de modo a não permitir conexão com a matéria disposta no instrumento contratual, levando o cliente a um fato inesperado, como a aquisição de um produto novo, além de cláusulas proibidas, as quais vêm atribuir ao Banco a decisão unilateral sobre as obrigações a serem adimplidas pelo cliente, principalmente quando não se for possível excluir as variações fundadas em índices objetivos de correção monetária. Ao faltar uma disciplina especial para ser aplicada aos contratos bancários, grande é probabilidade de aplicação das próprias cláusulas predispostas pelo Banco ou entidade financeira em cada caso concreto. Nesse sentido, entre as partes resta uma distância significativa, em que não há interferências, nem participações definidas, principalmente por parte daqueles que utilizam os serviços bancários.

Do mesmo modo no Brasil a fragilidade dos contratos ora firmados para dar aporte às operações bancárias desponta como prova concreta de um caos instrumental que afeta imediatamente a ligação entre Banco e cliente. Particularmente tem-se asșistido a uma completa ausência de efetividade, quando não muito, fraqueza sistêmica: situações envolvendo contratos leoninos, ilegíveis, impossíveis de serem cumpridos, revestidos de custos exagerados, aleatoriamente cobrados mediante débito em conta corrente, ou ainda a cobrança indiferenciada de juros rotativos no cartão de crédito sem notificação ao cliente. Essa pequena amostra reflete negativamente na eficiência do sistema de Direito Bancário e ataca a racionalidade da ligação relacional (conforme suscitado anteriormente, decorrência de variáveis ligadas à necessidade, pressão de consumo e métodos de publicidade agressivos). O cliente não pode simplesmente deixar de contar com o que o Banco lhe proporciona, dai a grande dificuldade residir no fato de que aquele, enquanto cidadão e usuário, está vinculado às operações, que este, enquanto

32. cf. Olivcira Ascensão, José. "Cláusulas contratuais abusivas nos serviços bancários c financeiros" In Revista Forense, vol.347, julho-sctembro, Rio de Janciro, Forensc, 1999. pp. $130 \mathrm{c}$ ss. 
uma instituição indispensável à vida econômica da sociedade, utiliza-se para exercer suas atividades. Parece um dilema, portanto..$^{33}$

A questão dos juros inseridos nos contratos bancários também exemplifica o impasse desencadeado. A sua estruturação decorre de uma exigência de ordem econômica, cujas conseqüências também importam para os instrumentos que o Direito ora apresenta para minimizar os resultados prejudiciais. Nem sempre, os juros são $a$ recompensa que aquele individuo (que tem dinheiro no momento) recebe do tomador; como forma de ser remunerado pelo sacrificio que fez ao abrir mão de um bem que poderia ser utilizado para outro fim..$^{34} \mathrm{O}$ mútuo, por exemplo, - quando informa um crédito para consumo, crédito pessoal, financiamento e outras operações ativas da atividade bancária-, leva junto de si a cobrança de juros e comissão de permanência (juros compensatórios ou retributivos) desde o momento em que o Banco dispõe ao cliente o dinheiro negociado. Ocorre, porém, que esses juros não são regulados pela Lei de Usura (Decreto n. 22.626/33), diploma que veda a fixação de juros acima da estipulação legal de $6 \%$ ao ano, mas pela Lei n. $4.595 / 64$, a qual prescreve a competência do Conselho Monetário Nacional para limitar, na medida do necessário, a taxa de juros das operações e serviços bancários. Essa orientação é reforçada pela jurisprudência do Supremo Tribunal Federal que, através da Súmula n.596, reiterou a inaplicabilidade da Lei de Usura às taxas de juros e outros encargos cobrados nas operações realizadas por instituições públicas ou privadas integrantes do Sistema Financeiro Nacional. Muitas vezes, os contratos bancários, frente a esse contexto, carregam consigo juros șuperiores a $12 \%$ ao ano, já que, na prática, o Conselho Monetário Nacional não limita, conforme seria sua competência, nem fixa, diante de exigências protetivas, uma taxa legal. Nas épocas de desvalorização da moeda, os juros reais oscilam e, para que a estabilidade seja alcançada, principalmente em um sistema fragilizado, o Governo propõe uma série de políticas econômicas que mantêm os juros em níveis elevados. Nesse momento, as implicações no mundo do Direito são preocupantes, já que essa oscilação de juros desestabiliza as operações bancárias, enfraquecendo os vínculos entre Banco e cliente. ${ }^{35}$ Em se tratando de um contrato de adesão utilizado pelo Banco, em que as cláusulas estão já formuladas e fixas, a oscilação dos juros reais da economia passa a elemento

33. A propósito, ver Wambier, Luiz R., ob.cit, pp.58 c ss; A csse respeito também, Menczes Cordciro, ob.cit., p.31, esclarecc: "Muito mais ponderosa é a quebra da relação bancária complexa: o cliente. ainda que inadimplente, temerá, antes do mais, o corte do crédito". Isso ć bem provável, já que, nessas circusntâncias, o individuo que contratou com o Banco o fez porque precisava de recursos para arcar com outras obrigações, ou ainda, sc cmpresário, fomentar a atividade que desenvolve. Dai a manutenção de uma rclação que lhe permita satisfazer determinadas necessidades

34. Nóbrega, Mailson e Loyola, Gustavo. "A Caderneta de Poupança c o Código de Defesa do Consumidor". In Revista de Direito Bancário e do Mercado de Capitais, n.6, ano 2, sctembro-dezembro, São Paulo, RT, 1999: pp. 260 c ss.

35. A respcito, ver Abrào, Nelson, ob.cit., p.72; Covello, Sérgio, ob.cit., pp.72 c ss; Wald, Arnoldo. "O Poder Monctário c suas repercussõcs no Dircito Previdenciário c Bancário" In Revista de Direito Administrativo, n.181/182, julho-dezcmbro, Rio de Janciro, Renovar, 1990. pp.46 c ss 
gerador de litigiosidade entre as partes envolvidas no contrato, trazendo prejuízos substanciais $^{36}$ Tendo isso como ponto de instabilidade, o aumento da inadimplência fecha o círculo vicioso aposto à relação Banco/cliente, porquanto no Judiciário se discute, inexoravelmente, os impasses gerados pela capitalização de juros, execução de cheques especiais, variação cambial, financiamento imobiliário e operações de leasing. ${ }^{37}$ A partir daí, surge a problemática concernente ao "auto-sacrificio": quanto maior a inadimplência, maior a fragilização do sistema de Direito Bancário, operandose uma inevitável transferência de custos, do cliente inadimplente para o cliente envolvido em obrigações já constituídas e para aquele que vier a constituir obrigaçõês no futuro.

Algumas situações de abusividade também vêm afetar a relação Banco/ cliente, principalmente quạndo os contratos bancários carregam consigo as chamadas "cláusulas-mandato", como aquelas que outorgam ao Banco o poder de designar, para o cliente, um procurador investido de faculdades especiais, como a de emissão de títulos cambiários destinados a lastrear a cobrança de um débito eventual. Isso se manifesta explicitamente, tanto no caso de um mútuo com fim de crédito para consumo, como quando o Banco confere à Empresa administradora de cartão de crédito o poder de emitir títulos cambiais que representem o saldo devedor do cliente, titular do cartão. Esse tipo de comportamento é lesivo à própria ordem bancária, gerando litígios desnecessários e que agridem ainda mais o funcionamento do sistema. ${ }^{38} \mathrm{Em}$ outros casos, também, é bastante comum a utilização de cláusulas que vedam a participação do cliente em tratativas relacionadas a determinados contratos, como o de conta corrente e financiamento a longo prazo, quando ele poderia optar pela forma mais interessante de desenvolvimento da operação e não ter de se submeter a determinado serviço acessório como o débito automático, poupança vinculada e outros do mesmo teor. ${ }^{39}$ Mais uma vez, fica claro como a inserção de uma cláusula como esta, proibițiva de conduta do cliente, impõe a fragilidade às relações estabelecidas. A atuação contratual do Banco, nestes casos, reforça, justamente, a posição dominante que ele assume enquanto criador unilateral de situações estanques, da quais o cliente apenas participa enquanto destinatário de prestações incertas.

Uma outra situação curiosa é revelada pelo comportamento do cliente em contratos bancários de abertura de crédito em conta corrente e a respectiva resposta

36. cf. Rizzardo, Arnaldo, ob.cit., p.67

37. cf. Wald, Arnoldo, "Patologia do Dircito Bancário: causas c soluçōes", ob.cit., p.43.

38. A respcito disso, existem mecanismos legais que vêm proteger o clicntc, como já na Europa prevêcm as Dirctivas n. 87/102 de 1986 da CE, coibindo notas promissórias c Ictras de câmbio emitidas para prestar garantia do crédito ao consumo, c a Súmula $n .60$ do STJ, que estabclece a nulidade da obrigação cambial assumida por procurador do mutuário vinculado ao mutuante, no cxclusivo interessc destc. Sobre csse assunto, De Lucca, Newton. Direito do Consumidor: Aspectos práticos, São Paulo, RT, 1995. pp.122 c ss.

39. cf. Stiglitz, Gabricl A., ob.cit., p.85 
da jurisprudência. Em muitos casos, o cliente restitui uma quantia superior do que realmente utilizou do montante oferecido pelo Banco na operação em questão. Pagase a mais porque se acredita na infalibilidade da instituição financeira e de seus serviços, sendo certo que, em algum momento, o Banco irá compensar o valor pago. Ou ainda, porque o cliente geralmente pretende evitar ajuizamento de ação de cobrança, atos de protesto, enfim, para não ser oportunado. Nesse sentido, e tendo notado que o valor pago a mais não foi compensado, vem pedir em juízo a repetição do pagamento. Os tribunais, sem compreender a razão pela qual o cliente foi levado a tal comportamento, aplicam os princípios de erro de direito, em sentido de excessiva literalidade. $O$ cliente, então, perde a pretensão de reaver o que pagou a mais, além dos juros que haviam sido deduzidos do pagamento outrora efetuado. ${ }^{40}$ Com efeito, por essa circunstância, o enfoque do problema expõe a atuação da jurisprudência no sentido de propiciar a manutenção da fragilidade de contratos como este, compreendidas, também, em outras hipóteses, como crédito para consumo, lançamento de débito em conta de depósito, pagamento de cartão de crédito em conta corrente e muitas outras operações de que o cliente vai se utilizar. Nelas, certamente, ele estará numa posição de desvantagem, pouco protegido, principalmente quando evidente que os tribunais insistem em dar respostas fundadas em remédios jurídicos tradicionais.

Estas foram algumas observações concernentes aos problemas que, de um modo geral, afetam a relação Banco/cliente em sua funcionalidade, confirmando que, em muitos casos, as situações negociais encetadas estão destituídas de segurança e de participação efetiva, além de revelarem que o poder contratual está a priori concentrado em uma das partes. Nás linhas que se seguem, esta última observação será explorada brevemente, sendo consideradas as razões que a informam dentro da institucionalização do Banco-Empresa.

\section{Poder Institucional do Banco e Contratação}

1. O Banco reconhecido em seu poder institucional. Quadro estrutural de inserção do Banco na sociedade contemporânea.

No exercício de sua atividade, o Banco confere aporte jurídico a várias operações que desenvolve, de modo a coordenar a relação Banco/cliente em sua dinâmica própria. Assim como já observado, tantos podem ser os contratos firmados entre as partes envolvidas nessa relação quanto maior a necessidade em jogo, a pressão de consumo e a vinculação intersubjetiva. Não existe um "concurso de vontades" apontado para um fim colimado, porém uma diretiva que ordena a conformação das relações estabelecidas entre as partes em questão e que, por sua natureza, suscita problemas variados.

Nesse sentido, como visualizar as relações entre Banco e cliente, quando aquele apresenta um novo sentido, quer no tocante da alocação do crédito, quer na

40. Rizzardo, Arnaldo, ob.cit., pp.66-67 
multiplicação de contratos, situação em que a instituição financeira toma para si o condão de criar verdadeiras normas jurídicas?

De todas as características assumidas pelo Banco, o poder institucional de que ele se reveste é substrato nuclear para que, dia a dia, novas relações sejam criadas e extintas, ou, se já existentes, mantidas e aprimoradas. Esse poder institucional, que faz do Banco-Empresa um agente social reconhecidamente indispensável à economia, hábil para captação de recursos e para destinação dos mesmos, é responsável pela dimensão dos vínculos mantidos com os clientes. Nesses vínculos, tradicionalmente, a função da instituição financeira é centralizar a oferta e procura de capitais, ora retirando, ora colocando-os nas mãos daqueles que sabem como tornar produtiveis os recursos e, também, nas mãos daqueles que não sabem como empregálos eficientemente. ${ }^{41}$

Entretanto, dentro de qualquer contexto sócio-econômico em que as riquezas convergem para pontos específicos, tamanho é o poderio de uma instituição financeira que, caso não seja bem utilizado, acaba por propiciar um quadro malacabado de relações com seus usuários. Eis a razão pela qual, freqüentemente, a fragilidade estrutural nessas relações se consubstancia, notada sempre que a distância entre Banco e cliente é demarcada, tanto pelo domínio de técnicas que levem à preponderância da instituição bancária, quanto por atender às demandas de uma sociedade de consumo. ${ }^{42}$

Para que se chegue ao quadro atual de inserção do Banco no mundo contemporâneo, no qual ele tem conquistado um espaço especial por dirigir a relação Banco/cliente, intermediando crédito, ofertando produtos e serviços e atendendo às expectativas de consumo, vários estágios se alternaram, de modo que, ao passar dos anos, houve um fortalecimento de sua presença na sociedade.

A institucionalização do Banco é fato notável na história, como quando em 1782 os EUA inauguraram sua primeira casa bancária, antes mesmo da adoção de

41 cf. Carvalho de Mendonça, José Xavicr. Tratado de Direito Comercial Brasileiro, $3^{a}$ cdição, v.VI, Livro IV, Rio de Janciro, Freitas Bastos, 1939. cspccialmente pp. 18 c ss. Assim também, curiosamentc, a Bíblia Sagrada traz passagens sobre um scntido para a função do Banco, como o de dar utilidade aos recursos $\mathrm{cm}$ geral, cnquanto cstcjam nas mãos das pessoas, saibam clas ou não como cmpregá-los. Dc fato ć o que se obscrva na Parábola dos Dez Talentos (Matcus, 25.14-30), sobrc o homen que cntregou scus bens a três servos, $\mathrm{c}$ um deles cnterrou o dinheiro recebido. Posteriormente toi reprecndido pelo seu senhor, que o advertiu para que tivesse cntregado o dinhciro aos banquciros c dai obter os juros do bem guardado. Também algo parecido ocorre na Parábola dos Dez Servos'e das Dez Minas (Lucas 19.11-27), $\mathrm{cm}$ que um homem pede aos scus scrvos para negociar as dez minas, $\mathrm{c}$ um deles csconde a recebida num lenço, sendo advertido pelo scu scnhor por não a ter dcixado para os banqueiros, os quais a fariam render juros.

42. Não-somente cm relação aos usuários tal problema acontecc, mas também dentro do sctor do mecado cm que o Banco atua. A cssc respcito, Calixto Salomão Filho, ob.cit., pp.67 c ss., advcrte para a utilização estratégica do poder finacciro, por exemplo, a fim de enfrentar gucrras de preços, suportar períodos clásticos, nivcis de preços inferiores aos custos, enfim, quaisquer outras práticas que permitam climinar concorrentes no mercado. 
uma Constituição. Modernamente, o Banco alcançou o status de centro das finanças modernas, buscando para si um ambiente competitivo, centralizador de serviços, canalizador de recursos e envolvido por um sistema jurídico particular, em que a presença do Estado se tem minimizado: da intervenção para o controle. ${ }^{43}$

No Brasil, a história também selou o poderio dos Bancos, principalmente porque, criada em 1808 a primeira instituição bancária, quando o país ainda era sustentado por uma economia eminentemente agrária, calcada em uma estrutura social paternalista, a eles foi atribuído, indiretamente, o papel de incentivo ao "capitalismo financeiro nacional", primitivamente, através de operações de depósitos e emissão de títulos cambiais, a exemplo do que ocorria, há muito tempo, na Europa. Dava-se início ao período em que o Estado passa a intervir no funcionamento do sistema financeiro, editando normas para tutela do crédito e estímulo ao funcionamento da atividade bancária. ${ }^{44}$ Foi exatamente com a edição da Lei n. 4.595/64, a impor um sistema financeiro tipicamente brasileiro, que se desencadeou um processo contínuo de fortalecimento do Banco. No caso brasileiro, curiosamente, os Bancos obtiveram muitos recursos por pouco investimento, além da possibilidade de expansão através de agências por todo o território nacional. O papel do Estado, nesse sentido, foi fundamental para justificar esse aparente paradoxo, além do que explica o êxito alcançado, no passado, por muitas instituições financeiras. ${ }^{45}$

Todavia, essa oportunidade histórica não tem mais lugar na atualidade, já que a globalização econômica, encurtando distâncias e concentrando atividades nas mãos de poucos agentes, fez com que o Banco passasse por etapas de transição: de um estágio a contar com o Estado para socorrê-lo, principalmente em situações emergenciais, para um estágio de sobrevivência. Há vezes, também, em que convive com medidas anticoncorrenciais, quando o Governo, acidentalmente, por alguns de seus regulamentos, cria situações embaraçosas para a saúde das instituições financeiras. ${ }^{46}$

Na Europa, por exemplo, o setor bancário passou por transformações substanciais, inserido num mercado unificado, com estratégias reformuladas, tanto em nível local quanto regional. A realidade calcada no Direito comunitário permitiu a diminuição da concorrência, fato que desafia as instituições do setor, principalmente porque a tendência observada é a formação de conglomerados empresariais. $O$ fenômeno de concentração também tem ocorrido no Brasil, em resposta ao processo de fusões e aquisições realizadas, basicamente, ao longo da década de 90 . Em 1998, o número de estabelecimentos caía de 246 para 203 e os dez maiores Bancos do País detinham 70\% dos ativos totais do mercado. Tal situação até hoje tem sido contínua, em que pese o

43. cf. Recd, Edward W. c Gill, Edward K, ob.cit,, pp. 18 c ss.

44. cf. Covello, Sćrgio, ob.cit.,pp.17 c ss.

45. Abrão, Nclson, ob.cit., pp.10 c ss.;

46. Recd, Edward W. c Gill, Edward K, ob.cit., pp.19 c ss; c Salomão Filho, Calixto, ob.cit., p.69. 
processo de concentração comportar-se como uma constante. ${ }^{47}$ Nos EUA também houve tendência para que a concentração ocorresse, porém o fenômeno nunca foi novidade. Acontece desde o Pós Guerra, como o fortalecimento das grandes corporações. Hoje o cenário norte-americano enfrenta um período de transição entre a regulamentação e desgulamentação do setor bancário, principalmente por que o governo está inserido num dilema: atar a movimentação da economia em sua dinâmica à proteção da poupança do público investidor. Ainda não se chegou a uma resposta para a abertura do setor ou um controle maciço. ${ }^{48}$

Hoje, também, no que concerne à organização da instituição financeira, há destaque para a moldagem ao Banco Múltiplo, fruto da racionalização dos conglomerados empresariais financeiros. Redirecionando custos e investimentos dentro da economia, a instituição bancária vai se aproveitar do encaixe perfeito ao regime da "empresa flexibilizada". em moda no cenário nacional, para, cada vez mais, livrar-se de organogramas e atingir níveis de produtividade que julga adequados, o que the embute a necessidade de contratar em massa. Assim, as antigas "instituições mercantis" fundamentalmente calcadas na intermediação do crédito passam à lógica empresarial, em que fornecimento de serviços e satisfação de necessidades constituem-se novas peças da organização financeira. O Banco-Empresa ocupa, portanto, uma posição de destaque na sociedade contemporânea, mais especificamente num momento em que o Estado vai saindo de cena. Logra, com isso, o caráter de "instituição total", 49

O retrospecto histórico feito até aqui mostra como o Banco ajustou-se no cenário da modernidade, alcançando novos perfis. As informações até aqui examinadas serão úteis para complementar o estudo de como a individualidade da instituição financeira no mundo de hoje pode orientar a relação Banco/cliente, sob o aspecto de uma habilidade que promove a contratação em massa, envolvida, assim, por uma racionalidade própria.

2. A instituição bancária enquanto produtor normativo e sujeito centralizador do poder contratual.

47. Assim, Orsi, Ricardo Vicira."A Tranformaçào do Papel do Estado frente a Crisc Bancária na União Européia." In Revista de Direito Bancário e do Mercado de Capitais, v.7, ano 3, janciro-março, São Paulo, RT, 2000. pp. 69-102. O dilcma curopcu consistc $\mathrm{cm}$ prescrvar a saúde das instituiçōcs financciras $\mathrm{c}$ do sistema bancário, sem o comprometimento da ordem juridica comunitária, o que implica a cdição de muitas dirctivas para tentar apaziguar o problema; No que toca o problema brasilciro, ver Gardenali, Gcraldo."Discutindo a livre concorrência no Sctor Bancário". In Atas do Seminário Internacional sobre Regulação e Defesa da Concorrência no Setor Bancário, São Paulo/Brasília, CADE-ASBACE, 1999 , pp. 401 c ss. Sobrc os números atuais dos Bancos, atć final de 2000, as instituiçõcs poderão chegar à casa dos $190 \mathrm{c}$ o número de agências, 16,2 milhões no País todo. cf. Brasil em Exame, suplemento da Edição 727 da Rcvista Examc, agosto/2000. pp.108 c ss

48. cf. Recd, Edward W. c Gill, Edward K., ob.cit., pp.299 c ss.

49. Assim, Wald, Amoldo. "Banco Múltiplo". In Revista de Direito Mercantil, n.64, ano XXV, outubrodezembro, São Paulo, RT, 1986, pp.9 c ss; c Barbosa, Livia, O Novo Papel da Empresa, Revista Examc, cdição 737, ano 35, Editora Abril, 200I. p. 109 
O Banco, dentro da perspectiva da globalização econômica, além de integrar-se a um espaço peculiar na sociedade, vem assumir papel importante na produção do Direito, principalmente pela saída do Estado do contexto tradicional, em que este vai aos poucos perdendo o monopólio da produção normativa. Assim, em face das lacunas entre um Estado-Nação e um Estado-gestor, o Banco fomenta seu próprio poderio normativo, atuando dentro de um setor específico da sociedade no qual se prevê não somente a alocação do crédito, mas também o fortalecimento de uma entidade especialíssima na dinâmica do processo de criação de normas. Estas normas dão margem de cobertura para as operações que são encetadas na atividade bancária, e aí, a grande variedade de contratos que são "fabricados" pelos Bancos, como um das decorrências desse poder normativo alcançado.

Com efeito, essa habilidade do Banco em promover contratos em massa tem seu espaço dentro da experiência das corporações financeiras. Estas, como analisa José Eduardo Faria ${ }^{50}$. estão inseridas no fenômeno do pluralismo jurídico, onde criam complexas redes normativas, firmam tratativas negociais em escala mundial, com regras próprias, buscam auto-resolução de conflitos, formam uma cultura normativa imanente e regulamentam as operações técnicas desenvolvidas. O que ocorre com o Banco é a manifestação de um poder próprio, decorrente da sua institucionalização na sociedade moderna, na qual ele certamente contaria com um lugar garantido dentro do fenômeno da "hipercomplexidade" contexto este descrito pela multiplicidade das fontes do Direito, de valores e de juízos sociais justapostos uns aos outros, e em que cada instituição da sociedade clama por normas especiais para si, como se tal propósito fosse dar fim aos problemas estruturais que ali incidem.

Daí se segue que, na falta de regimes especiais e oficiais, o Banco vem se tornar centro difusor de contratos, tal qual uma máquina a operar, de números a normas, a fim de estabelecer situações, vincular comportamentos, definir padrões e sancionar o descumprimento de regras pré-estabelecidas, culminando num impasse: de um lado conhecer as necessidades atuais e futuras dos clientes, e aí propor-lhes uma solução já pronta; de outro, a exigência de garantias para que as obrigações constituídas venham ser adimplidas, de modo a priorizar a solvência da instituição. Com efeito, no desenvolvimento de seu intento empresarial, o Banco vem trazer diversos instrumentos para articular os pólos desse impasse, desde quando detém o domínio de tecnologias informacionais até o momento em que conta com um ótimo corpo de advogados que se empenha em flexibilizar a apreciação dos litígios por meio de arbitragem e transações informais.

Neste cenário, todavia, contratos complexos são criados, sucessiva e aleatoriamente. $\mathrm{O}$ cliente apenas ingressa nas expectativas, principalmente sob vários aspectos, como pela unilateralidade, quando os atos se concluem por simples assinatura

50. O Direito na Economia Globalizada, São Paulo, Malhciros, 2000. pp.157 c ss.

51. Sobre o fenômeno da hipercomplexidade, ver Junqueira de Azevedo, Antonio. “ O Dircito pósModerno c a Codificacação", ob.cit., pp.4 c ss. 
de cartas, dispensando a regra da proposta e aceitação, tradicionalmente apensa à autonomia da vontade; pela rapidez, porquanto todas as relações constituídas se dêem indefinidamente, sem que o Banco tenha que dar muita atenção para um cliente apenas, já que muitos outros devem ser captados através de outros contratos; e pela desmaterialização, quando do aporte da Informática para o fechamento dos acordos, em que a impessoalidade é nota fundamental, o que leva à diminuição dos laços de fidelidade e confiança entre as partes, além da delegação de serviços para outras entidades, como ocorre no tocante das administradoras de cartão de crédito. ${ }^{52}$ Assim também, e detendo um know-how próprio, o Banco vincula o cliente em seu patrimônio, faz proliferar contratos embasados nas necessidades, em torno de situações muitas vezes propícias a que isso ocorra, como a eventual estabilidade financeira de um país e a criatividade das medidas e investidas de marketing para o convencimento do cliente de que ele "realmente" precisa de um dado serviço oferecido pela instituição bancária.

De tudo isso, a relação Banco/cliente vem se travar em torno de um vínculo intersubjetivo, manifestado-se em grau de complexidade por força de todo aquele aparato que deixa o Banco-Empresa numa situação muito mais favorável. Este internaliza o cliente na organização bancária e, assim, pode estabelecer os contratos que sustentam as operações numéricas desenvolvidas, de modo que os serviços sejam sempre minuciosamente disciplinados a fim de que os usuários não tenham muito que questionar, bastando a integração nos esquemas que lhe são apresentados.

\section{Proteção do Consumidor no Âmbito no Direito Bancário}

\section{Problemas estruturais. Como operar as peças Banco/Cliente no Sistema do Código de Defesa do Consumidor.}

Como se foi observado em linhas anteriores, é possível conceber que o contexto das relações Banco/cliente vem se tornando, dia a dia, redefinido em sua funcionalidade. Primeiro numa perspectiva em que as partes envolvidas são desprovidas de um controle equânime da estrutura dos contratos concluídos. Segundo porque entre elas existe uma distância de ordem institucional. Ambos fatores têm dado margem para que, muito freqüentemente, os mecanismos do sistema nacional de defesa do consumidor sejam invocados, enquanto aporte jurídico para solução dos problemas dentro do âmbito do Direito Bancário.

Freqüentemente, existe um impasse quanto à admissão ou não do Direito do consumidor no plano dos contratos bancários. A esse respeito, o dissenso jurisprudencial consubstanciado no Direito brasileiro conduz os conflitos protagonizados entre a instituição bancária e os seus usuários à incerteza e seletividade no tocante às decisões proferidas. Com efeito, esse fenômeno é bastante visivel em cada parte do

52. cf. Menczes Cordciro, Antônio, ob.cit., p.3I; c Recd, Edward W c Gill, Edward L, ob.cit., p.20 c ss. 
País, refletindo diferentes mentalidades sobre a vida e dinâmica do Direito, prova cabal do maior ou menor grau de conhecimento a respeito do tema, da ausência de criticidade e falta de percepção das mutações sistêmicas. ${ }^{53}$

Por essa razão, dentre outras que apareçam, vale fazer uma retrospectiva sobre a defesa do consumidor e o seu relacionamento com o Direito Bancário, a fím de observar os problemas de entrelaçamento das matérias e enquadramento de conceitos.

A matéria sobre Direito de consumo foi inserida no plano constitucional brasileiro, em 1988, enquanto peça de um modelo principiológico welfarista, consoante a promessa de o Estado-gestor tutelar situações de manifesto desequilibrio econômico entre os cidadãos, intervindo por meio de mecanismos corretores. Concebido em caráter de norma programática, vem o art. $5^{\circ}$, inciso XXXII, enunciar: "O Estado promoverá, na força da Lei, a defesa do consumidor", o que de certo modo veio a ser atendido pela Lei n. 8.078/90- Código de Defesa do Consumidor, marco de mudança no sistema de Direito contratual. Não obstante a essa previsão fundamental, a Constituição de 1988 apresentou a defesa do consumidor no rol dos princípios da ordem econômica (art 170, V) e, conforme analisa Fábio Konder Comparato ${ }^{54}$ vem integrá-la num plano de hierarquia semelhante ao da prerrogativa de livre concorrência, livre iniciativa e liberdade da Empresa. Assim, o caráter constitucional da defesa do consumidor alcança inequívoca singularidade, daí o que a torna baliza para uma série de situações jurídicas do cotidiano, em que, constantemente, negócios de massa são travados entre os cidadãos.

A aplicação do Direito do Consumidor não poderia ficar adstrita ao plano dos negócios de consumo, principalmente porque o cenário da economia de massa e dos contratos celebrados por meio de adesão ou cláusulas contratuais gerais, como as que existem no âmbito da relação Banco/cliente, impõe uma nova reflexibilidade sistêmica. Uma vez admitido o complexo normativo do regime trazido à baila pela Lei n. 8.078/90, é possível chegar a duas linhas conclusivas: i. propugnar pela tentativa de superação dos problemas concernentes à correspondência entre o sistema financeiro nacional e o sistema de defesa do consumidor, encarando, quando possivel, a relação Banco/cliente em sua faceta fornecedor/consumidor, ${ }^{55}$ e ii. conceber as normas

53. Veja, por excmplo, o trecho transcrito da decisão proferida no Tribunal de Justiça do Mato Grosso: "As normas contidas no CDC não se aplicam às operações de empréstimo fétas pela instituição financeira. pois o banco e o cliente não se enquadram nas definiçòes de fornecedor; prestador de serviço e de consumidlor contidas na lei". (Ap 22.145-13/02/97: Revisıa dos Tribunais, ano 86, v.744, São Paulo, RT, 1997). De modo diverso, veio o Tribunal de Justiça do Rio de Janciro propor: "Em principio cumpre observar que a ativiılade da instituição financeira equipara-se a serviço, nos moldes do parágrafo 2 "do art. 3" do CDC e que há, portanto, uma relação de consumo entre o banco e o cliente, nada inpedindo que o julgador proceda ao exame das cláusulas contratadas, especialmente àquelas que estipularem taxas abusivas ou ilegais, à luz do art. 5I. IV, do CDC, atentando-se a caracteristica do contrato de adesão e à vulnerabilidade do contratante" (Apcl. 196.227.468.-12/03/97: Revista dos Trbiunias, v. 744)

54. "A Proteção do Consumidor na Constituição Brasilcira de 1988". In Revista de Direito Mercantil, n.80, Ano XXIX, outubro-dezembro, São Paulo RT, 1990.pp.66-75

55. Almcida Salles, Marcos Paulo, O Consumidor e o Sistema Financeiro: Um comentário da Lei 8.078/90, São Paulo, Editora Acadêmica, 1991. pp. 8 c ss. 
constitucionais e do Código de Defesa do Consumidor enquanto peças de um microssistema a regular a própria contratualística brasileira ${ }^{56}$

Dentro do universo das relações de consumo, e inferindo-se pela aplicação das normas de Direito do Consumidor ao âmbito do Direito Bancário, a instituição financeira pode assumir a posição de prestadora de serviços, dispondo a seus clientes uma série de produtos. O Banco-Empresa-intermediadora torna-se igualmente Empresa-fornecedora e o cliente-cidadão, poupador e usuário, é cidadãoconsumidor.

A dificuldade de se delimitar as posições encetadas pelo Banco e cliente no contexto das relações assumidas no campo das atividades financeiras e transportálas ao âmbito do Direito do Consumidor tem fomentado alguma discussão. Em algumas hipóteses, é possível enquadrar os sujeitos das relações bancárias nos conceitos fornecidos pelo Código de Defesa do Consumidor, fazendo-se a conexão Banco à posição de fornecedor e cliente à posição de consumidor. Mas, como fazer essa ponte quando observada a tradicional essência da atividade bancária, vista por J. X. Carvalho de Mendonça, ${ }^{57}$ como a intromissão entre o que o Banco dispõe de capital e o quanto deste o cliente precisa, binômio do recebimento e concentração de capitais, aptos a serem sistematicamente distribuídos por meio de operações de crédito?

Semelhante ao que ocorre na Europa ${ }^{58}$ a atividade bancária, em determinadas situações, adquire o caráter de serviço, em resposta a que, não obstante suas limitações, o $\S 2^{\circ}$ do art. $3^{\circ}$ do Código de Defesa do Consumidor pretende ${ }^{59}$. Essa idéia tem sido muito discutida, já que os litígios levados aos tribunais, envolvendo atividades financeiras e securitárias, desviam-se para a incidência de esquemas calcados na legislação e práticas comerciais, o que nem sempre pacifica os problemas suscitados. ${ }^{60}$ Somente em alguns casos, como a cobrança, a venda de seguros, o

56. Assim, Lobo, Paulo Luiz Nctto, ob.cit., pp. 243 c ss; c Coclho, Fábio Ulhôa, ob.cit, p. 130.

57. Tratado de Direito Comercial Brasileiro, vol.VI, Livro IV, p.14.

58. Assim, Rivitti, Maria Augusta da Matta. "O Conccito de Consumidor c o Dircito Bancário no Dircito Comparado". In Revista de Direito Banćário e Mercado de Capitais, n.6, ano 2, sctembro-dezcmbro, Sào Paulo, RT, 1999. pp.283 c ss.

59. Uma das questões colocadas $\mathrm{cm}$ cxame a cada jurisprudência construida no pais, ao tratar da rclação Dircito de Consumo/ Dircito Bancário, Icvanta os problcmas da definição atribuida a scrviço, cnquanto toda atividade fornecida no mercado de consumo, mediante remuneração, inclusive as de natureza bancária, financeira, de crédito e securitária, salvo as decorrentes de relação de caráter trabalhista. $\mathrm{O}$ alcance do referido artigo, na maioria das vezes, ć invocado para dar soluções aos contlitos aprescntados $\mathrm{cm}$ juizo, mas nem scmpre proporciona uma resposta satisfatória no tocante à proteçào das partes realmente cnvolvidas cm prejuizo cfetivo. cf. Wambicr, Luis Rodrigucs, ob. cil. p.58

60. cf. Efing, Antônio Carlos, ob.cit., p.52. Com ficito, a questào lcm siclo levantada há anos na doutrina, como, por exemplo, resumida no entendimento de Luis Gastão Pacs de Barros Leãcs ("As Relaçõcs de Consumo c o Crédito ao Consumidor". In Revista de Direito Mercantil, 11.82 , ano XXX, abril-junho, São Paulo, RT,1991, pp|3-23), que assim analisa: "Não tem a lei intenção de determinar a absorção, à legislação e proteção do consumidor; de todo e qualquer serviço de crédito de on de financiamento, ou ainda seguros, mas apenas àqueles relacionados com o mercado de consumo. ou seja. com o mercado vinculado à venda em massa, de bens ao público consumidor" 
recebimento de contas, impostos ou taxas, e a transferência de valores é que são considerados serviços prestados, já que, tecnicamente, a atividade ordinária de intermediação realizada pelas instituições bancárias, como ocorre no caso da poupança, não oferece um produto a consumo. ${ }^{61}$

Outras figuras, no entanto, muito mais freqüentes no cotidiano do Banco, como as concernentes à concessão de crédito ao cliente, têm trazido discussões à problemática da aplicação do Direito do Consumidor. Poderá ser o crédito objeto de consumo dentro da perspectiva do Direito Bancário? A resposta é afirmativa se for possível argumentar a correspondência expressa entre negócios bancários e relações de consumo, daí conceber o crédito enquanto bem jurídico consumível..$^{62} \mathrm{Na}$ hipótese de o Banco conferir o crédito para consumo - em que o cliente, pessoa fisica ou jurídica, é destinatário final, é possível a aplicação das normas de direito do consumidor. Tal idéia vem sendo consignada na distinção feita por Nelson Nery Júnior ${ }^{63}$, em que $o$ autor reconhece haver relação de consumo quando há outorga de dinheiro para que o devedor o utilize como destinatário final, daí a aplicação das normas do Código de Defesa do Consumidor. Por outro lado, caso o cliente tome dinheiro do Banco para repassá-lo não será destinatário final e, portanto, a relação de consumo, analiticamente enfocada, fica descaracterizada.

Com efeito, se o cliente utiliza o crédito, objeto de um mútuo celebrado entre ele e o Banco, para a finalidade de adquirir bens e serviços oferecidos no mercado, é bem provável que a relação estabelecida esteja compreendida no plano da defesa do consumidor. Nos EUA, por exemplo, a figura do consumer credit ganhou atenção do sistema de defesa do consumidor, quando, desde 1968, a legislação consumeirista advinda do Consumer Credit Protection Act veio estabelecer, em seu titulo I Truth Lending Act -, o regime de tutela ao consumidor envolvido nas operações financeiras vinculadas ao fornecimento de bens e serviços. ${ }^{64}$ Tal particularidade estará prevista, portanto, na operação que atribui ao Banco o status de fornecedor e ao cliente o status

\footnotetext{
61. Tal caracteristica ć perceptível quando se atribui à atividade de intermediação o caráter de captação de recursos para investimento, $\mathrm{cm}$ que o Banco dá ao dinhciro do cliente a destinação para fomento de outras atividades, inclusive cmpréstimo a terceiro, comportando-sc cnquanto estoque físico de capital. No caso da poupança, $\mathrm{cm}$ particular, ć possivel que o Banco destinc os recursos poupados para consumo de terceiro, sob a figura do emprćstimo para consumo, remunerando o poupador com juros, pelo tempo que deixou scu dinhciro na instituição. Cf. Nóbrega, Mailson c Loyola, Gustavo. ob.cit., pp. 264 c 265 . A jurisprudência do STJ, no entanto, firmou entendimento de que o CDC ć aplicável às cadernetas de poupança. Porcm, não sob o cnfoque de comparar a atividade financcira ai cnvolvida a uma rclação de consumo. Acredita-se mais $\mathrm{cm}$ que a Lei n. 8.078/90 deva ser aplicada nas hipóteses de o cliente poder reaver pagamento de diferenças de índices de correçào monetária c na possibilidade de entidades, como IDEC, ajuizarem ação civil pública para defender os interesses dos poupadores. Parecc, pois, restar cristalina a intenção da corrente jurisprudencial formada no sentido de ampliar a incidência da defesa do consumidor do âmbito bancário.
}

62. A cssc respcito, Casado, Marcio Mclo, ob.cit., pp. 27 c ss.

63. cf. Código Brasileiro de Defesa do Consumidor, Rio de Janciro, Forense, 1991, pp.305 e ss.

64. cf. Barros Lcācs , Luis Gastão Pacs, ob.cit., p.21 
de consumidor, além de mostrar que o crédito torna-se objeto desta relação e daí ser consumivel.

Todavia, a previsão formal acima descrita revela problemas de ordem estrutural, principalmente quando o jurista se deparar com uma operação restritiva de enquadramento de conceitos. É simples perceber, porém dificil explicar todas as situações em que se pretende atribuir ao cliente o caráter de destinatário final de um serviço e ao Banco, o caráter de fornecedor do mesmo. Isso acontece no caso de se ter de recorrer reiteradamente aos pressupostos da relação de consumo, além da verificação mecânica da inserção dos sujeitos da relação jurídica bancária nesse modelo. ${ }^{65}$ Talvez aí resida uma certa dificuldade, que se acentua pelo fato de a realidade educacional e cultural do país nem sempre lidar com a habilidade de fomentar a defesa do consumidor e, mais ainda, transplantar tal prerrogativa para o campo do Direito Bancário, no qual as relações configuradas nem sempre estão ao alcance de uma jurisprudência inovadora.

2. Propostas para uma melhor alocação dos contratos. Proteção do cliente em face de um regramento contratual mais favorável.

A discussão sobre o enquadramento do cliente à figura do consumidor e do Banco à figura do fornecedor pode suscitar, como analisado anteriormente, várias dificuldades do ponto de vista conceitual (no que concerne aproximar atividade bancária à serviço), além de problemas estruturais, quando quando daquelas situações em que a jurisprudência não sabe operar o aproveitamento do Direito do Consumidor às demandas dos contratos bancários. ${ }^{66}$

Pois bem, admitindo-se que impasses como esses precisam ser superados, ao jurista cabe a reformulação dos esquemas, embasando-se em um modelo de regramento que leve em conta a proteção das partes envolvidas e a concretização das expectativas inseridas nos negócios. Isso permite trazer ao Direito Bancário princípios que possibilitem a construção de esferas protetivas, mitigando-se os prejuízos e prevenindo-se quanto à onerosidade que muitas vezes incide sobre o cliente, cuja posição na relação contratual bancária investe-se de um desequilíbrio substancial e institucionalizado. Como poderia, então, a sistemática do Direito Contratual brasileiro, enriquecida tanto por principios da Constituição, de 1988, como pelas normas do Código de Defesa do Consumidor, propor nova funcionalidade à relação Banco/cliente?

A questão não é tão difícil. Exige uma reflexão em torno de modelos tal qual uma matriz de incidência normativa que possibilite a tutela jurídica de uma das partes (enquanto modelo delimitador do poder contratual dominante que a outra parte

65. cf. Wambier, Luiz Rodrigucs, ob.cit., pp. 57 c ss.

66. Como se conclui do exame dos problemas anteriores, a dificuldade maior cstá $\mathrm{cm}$ se fazer a investigação por dois critćrios:i.-a finalidade do ncgócio bancário, se o clicnte ć ou-nào consumidor c dai sua vulncrabilidade; ii. sc a atividade bancária ć ou não um scrviço; caso sc constitui somente cnquanto atividade de intermediação, a cadeia de consumo não existe c o cliente ć meramente tomador de recurso para repassá-lo a outro individuo. 
impõe). Assim, tem-se um instrumental que pode previnir situações indesejáveis, ou em último caso, corrigir eventuais distorções. Com isso, manifestados enquanto elementos de uma série protetiva, propõe-se o resgate de certos valores, de que o Direito, como unidade que é, nunca pode se afastar:

2.1. Interpretação mais favorável em relação ao cliente. Trata-se de um princípio de hermenêutica no plano dos contratos de adesão que pode perfeitamente se adequar à relação Banco/cliente, já que permite dar apoio ao sujeito que figura no pólo que menos detém o poder de coordenar a estrutura funcional da relação contratual de que é parte. Esse critério, todavia, nem sempre estará conformado com os limites da legalidade, já que permite uma grande abrangência material, nem sempre ligada ao que à lei obriga a fazer ou deixar de fazer. Todavia, é uma peça útil para que a análise do contrato explicite a posição da partes e, assim, destacar o status do cliente diante da atuação do Banco no contrato, além das conseqüências eventuais da discrepância existente entre as partes. ${ }^{67}$

2.2. Boa-fé objetiva. Regra indispensável e de aplicação vinculante aos contratos em geral. Nada obsta que seja remetida ao Direito Bancário. Ela resume o agir com lealdade, fidelidade e coerência, neutralizando a parte que, no contrato, procure tirar vantagens excessivas e se firmar na posição mais fortalecida. Assim o cliente, não tendo participado da construção do contrato de adesão geralmente apresentado pelo Banco, requer um suporte objetivo a sua posição na relação. Nesta, a boa-fé deve ser enfocada objetivamente, enquanto fonte de deveres implícitos. Tal princípio, em sua juridicidade, tem justificação nos arts. $4^{\circ}$, III e 51 , IV do Código de Defesa do Consumidor, constituindo-se como barreira ao exercício abusivo de um direito subjetivo gerado no contrato, além da quebra do monopólio do poder contratual preponderante Machtposition -, corrigindo as vantagens excessivas e evitando a lesão. No caso do contrato bancário, qualquer que seja a sua finalidade, a boa-fé objetiva não pode ser afastada, de modo que seriam nulas as cláusulas ou convenções que visem diretamente eliminar ou simplesmente diminuir a exigência da boa-fé na formação e execução dos contratos. ${ }^{68}$ (grifamos)

2.3. Principio do equilibrio ou balanceamento. De grande importância, permite identificar um modo diferente de elaboração dos conteúdos juridicos presente nos contratos, verificando a "regra do julgamento", que não está justificada na vontade das partes, porém na responsabilidade, quando duas partes contratantes se empenham

67. cf. Olivcira Asccnsão, ob.cit., p.128; c Gomes, Orlando, ob.cit., pp. 109 c ss.

68. A propósito do referido principio no campo do Dircito contratual, ver Junqueira de Azcvedo, Antonio. "Boa Fć na Formação dos Contratos". In Revista do Direito do Consumidor, n.3, São Paulo, RT, 1992. pp.78-87; Sobrc o Dircito Bancário, Palharcs, Cinara. "Principios Constitucionais c Consumciristas informadorcs do Dircito Bancário" In Revista Juridica, n.267, ano 47, Sào Paulo, Nota Dez, 2000 pp.4653; Casado, Marcio Mcllo, ob.cit., p.42; c Lima Marques, Cláudia, ob.cit., p. 109 
em cumprir um acordo feito, tanto num patamar político (levar a cabo a prática contratual), quanto num patamar sociológico (levar em conta a estruturação da sociedade). Aplicado ao Direito Bancário, esse princípio asșume uma importância construtiva, já que a vontade do cliente-aderente nem sempre é aquela traduzida no contrato celebrado com o Banco, requerendo um mecanismo de balanceamento das forças envolvidas na relação, bem como aproximação das previsões contidas nas cláusulas à realidade concreta. ${ }^{69}$

2.4. Dever de informação. Fundamental ao tratamento dos contratos bancários, quando se prevê que uma parte, detentora de informações relevantes, seja compelida a transmiti-las para a outra parte, ainda na fase pré-contratual. Através desse comportamento, as dúvidas relativas aos efeitos do contrato são postas em relevo e, a partir daí, esclarecidas pela parte que concentra em si as informações necessárias. $O$ Banco, diante desse dever, estará obrigado a informar sobre a técnica do contrato, cumprindo uma "atuação pedagógica" mecanismo este preventivo, a fim de se evitar a litigiosidade e prejuízo, normalmente presentes no âmbito do Direito Bancário, além de estimular o cliente a procurar uma solução alternativa que mais lhe interesse. ${ }^{70} \mathrm{~A}$ admissão do dever de informação explicita a integração do princípio da transparência à relação Banco/cliente, no sentido de conscientizar o cliente acerca das situações envolvendo cobrança de juros, as taxas anuais e os acréscimos legalmente previstos. ${ }^{71}$ O dever de informação, por exemplo, é responsável pela eficácia de cláusulas permitidas, como ocorre quando o Banco comunica, com antecedência, ao cliente sobre a alteração da taxa de juros previstos em um contrato, e correspondêrncia com a variação no mercado. Do mesmo modo, ocorre o dever de informar quando se está diante da perspectiva de Banco-fornecedor, em que pese a instituição ser compelida a divulgar todos os riscos dos produtos que vende, tal como no que concerne à promessa de rentabilidade dos títulos de crédito. ${ }^{72}$

2.5. Interesse Público. No que se infere das relações despersonalizadas, cunhadas pela vinculação interindividual, em que pouco se resolve pela vontade das partes, fica um tanto comprometida a aplicação exclusiva de regras fundadas no Direito

69. Porto Maccdo Jr, Ronaldo, ob.cit., p.89; c.Palhares, Cinara, ob.cit., p.51.

70 A respeito do dever de informação, Cláudia Lima Marques, ob.cit., p.109, cxplica que cle scja decorrência do principio da boa-fé objetiva, cnquanto um dos "deveres ancxos", - Nebenpflichten -, assim como o dever de cooperação c o dever de cuidado nas tratativas negociais. Ver também, Menczes Cordeiro, Antônio, ob.cit., p.27

71. Esta imposição cstá explícita no $\mathrm{CDC}, \mathrm{cm}$ scu art. $52 \mathrm{c}$ incisos, a ressaltar o dever de informação prévia c adequada sobrc o montante dos juros de mora e da taxa cfetiva anual dos juros, sobre os acréscimos previstos, sobre a quantidade c periodicidade das parcelas, alćm do valor integral do crédito outorgado scm a inserção dos juros de financiamento.

72. cf. Rizzardo, Arnaldo, ob.cit., p.26; Olivcira Ascensão, J., ob.cit., p. 131; c Almcida Sallcs, Marcos Paulo, ob.cit., p.50. 
Privado, principalmente porque os Códigos Civil e Comercial foram esboçados quando, no País, tinha-se como lúcida a idéia de autonomia de vontade. Em face de um "concurso de vontades", hoje neutralizado pelo poder contratual do Banco e pela falta de participação do cliente na celebração do contrato, a necessidade de que os fins desse contrato sejam controlados e adequados ao interesse público surge como elemento imprescindível para a proteção, não somente da parte fragilizada, mas de toda uma coletividade, principalmente quando se tem em jogo outros valores, como o meio ambiente equilibrado e a integridade do patrimônio público. ${ }^{73}$

Dentro da perspectiva de um Direito Bancário que abre espaços para novas transformações, principalmente no que diz respeito à reformulação de seus aportes técnico-contratuais, a presença de princípios que possam minimizar os efeitos de uma eventual prejudicialidade no âmbito da relação Banco/cliente revela, mais uma vez, a necessidade de reflexão. Ainda que poucos deles tenham sido esboçados acima, porquanto muitos existam, a lógica do Direito Bancário se altera afastando-se de seus conceitos tradicionais e atinge um novo esquema em que seus elementos identificamse com os novos fenômenos da modernidade.

Assim sendo, e tendo sido concluídos os objetivos desse trabalho, é ainda uma obrigação atentar para que, tanto o "repensar o sistema", quanto "detectar-lhe as disfunções", perfazem, no momento, duas das grandes tarefas do jurista contemporâneo. Primeiro porque a lei não mais é paradigma, por excelência, da resolução dos conflitos, tal qual se comportasse como uma máquina auto-suficiente; segundo, porque os interesses, outrora ligados a uma racionalidade voluntarista, hoje atendem à conformidade de uma ordem social globalizada, dotada de novos anseios e preocupações. E, finalmente, porque o próprio Direito, em sua magnitude, trilha caminhos incertos, multiplica mais e mais questões e vem formar, ininterruptamente, novos conceitos. Com isso desafia o homem, deixando o estudioso do século XXI bastante perplexo.

São Paulo/Americana, abril de 2001.

73. Assim, por excmplo, ao firmar com o cliente um contrato de mútuo, o Banco sabe que a cle não cabe apenas a obrigação de dar - entrega do dinheiro -, porém não poderá fomentar um emprecndimento que acarrete danos ao meio-ambiente ou a bens de terceiros, porque, se o fizer, responde solidariamente pclo ato ilicito do cliente. Ora, nessa relação Banco/cliente, que tem como objeto um cmpréstimo, tipicamente regulado por normas de Dircito privado, ocorrc a sobrcposição da esfera do Dircito Público, como $\mathrm{cm}$ razão do interesse da colctividade c não atrelado ao mero interesse das partes. cf. Casado, André Mello, ob.cit., p.20. 